\title{
Dynamics of HIV-1 mRNA Expression in Patients with Long-term Nonprogressive HIV-1 Infection
}

\author{
Manola Comar, ${ }^{\star}$ Cecilia Simonelli, ${ }^{\prime}$ Stefania Zanussi, ${ }^{\S}$ Paolo de Paoli, ${ }^{\S}$ Emanuela Vaccher, ${ }^{\ddagger}$ Umberto Tirelli, ${ }^{\ddagger}$ \\ and Mauro Giacca* \\ * Molecular Medicine Unit, International Centre for Genetic Engineering and Biotechnology, 34100 Trieste, Italy; and ${ }^{\ddagger}$ Division of Medical \\ Oncology and AIDS, and ${ }^{\S}$ Division of Microbiology-Immunology-Virology, Centro di Riferimento Oncologico, 33081 Aviano, Italy
}

\begin{abstract}
A large number of evidences indicate that progression of HIV disease is driven by an increase in viral burden. It is still unclear, however, to what extent this is contributed by the dysregulation of the molecular mechanisms governing virus gene expression at the transcriptional or posttranscriptional levels.

To address this issue, several quantitative virologic parameters (including provirus transcriptional activity and splicing pattern) were analyzed in individuals with nonprogressive HIV infection and compared with those of a matched group of progressor patients. Exact quantification was achieved by a competitive PCR procedure using a multicompetitor template.

Nonprogressors were characterized by striking differences in the levels of viremia, provirus copy number, and overall levels of all viral mRNA classes in peripheral blood mononuclear cells. Additionally, the transcriptional activity of the proviral DNA in these patients was mainly engaged in the production of multiprocessed transcripts, with a pattern resembling the early phases of the experimental infection.

Taken together, these results show that both viral load and provirus transcription pattern are remarkably different in infected individuals nonprogressing toward overt disease, and further support the notion that disease progression is accompanied by a change in the kinetics of HIV gene expression. (J. Clin. Invest. 1997. 100:893-903.) Key words: provirus - transcription - acquired immunodeficiency syndrome $\bullet$ competitive polymerase chain reaction $\bullet$ pathogenesis
\end{abstract}

\section{Introduction}

During the natural history of clinical HIV infection, progression of the disease is paralleled by an increase of the amounts of infectious virus, viral antigens, and virus-specific nucleic acids in the patients. In general agreement with this notion are a number of studies that measured the viral load in serum by quantitative virus culture or quantitative polymerase chain reaction, the number of infected cells in peripheral blood and

Address correspondence to Dr. Mauro Giacca, Head, Molecular and Cellular Biology, ICGEB, Padriciano, 99, 34012 Trieste, Italy. Phone: 39-40-3757.324; FAX: 39-40-226555; E-mail: giacca@icgeb.trieste.it

Received for publication 6 February 1997 and accepted in revised form 19 May 1997.

J. Clin. Invest.

(C) The American Society for Clinical Investigation, Inc. 0021-9738/97/08/0893/11 \$2.00

Volume 100, Number 4, August 1997, 893-903

http://www.jci.org lymph nodes by PCR or by in situ methods, and the levels of HIV antigenemia by immunologic procedures (1-12).

In particular, the study of virus-specific mRNAs in peripheral blood mononuclear cells (PBMCs) ${ }^{1}$ by reverse transcriptase-PCR (RT-PCR) led to the conclusion that a strong correlation exists between cellular HIV mRNA levels and the clinical course of the disease $(9,13-15)$, often independently of CD4+ counts and clinical staging (16). Despite the overall agreement on these observations, it is still not clear whether the increased presence of virus-specific mRNAs in lymphoid cells of advanced stage infected patients reflects an increased expression rate of the provirus, as suggested by some observations $(2,9)$, or merely the expansion of the pool of infected cells (14). In fact, while a number of evidences clearly indicate the existence of a true latency state of viral gene expression in experimental settings (17-19), it is still debatable whether a role for latency exists in controlling the progression of the clinical infection (20-22).

Similarly, it is still not clear what is the role of the regulation of posttranscriptional processing of HIV-1 mRNAs in the progression of the disease. In HIV-1-infected cells, $>20$ different viral mRNAs are synthesized, deriving from a single full length messenger by multiple alternative splicing events (23, 24). Either during the infection of susceptible cell cultures $(25$, 26) or in cellular systems in which transcription is inducible $(17,18)$, a temporal regulation of the synthesis of these transcripts is detectable: initially, short transcripts are prevalent, encoding for regulatory proteins; subsequently, intermediate mRNAs (mostly coding for the Env proteins) and unspliced mRNA (Gag/Pol and viral genome) accumulate.

These experimental observations suggested that the pattern of production of viral transcripts could be linked to the development of infection also in vivo and could represent a marker of disease progression (27). However, controversial results have been obtained by measuring transcript classes in infected individuals: the finding that multispliced RNAs could be prevalent at early times of the disease while unspliced RNAs could predominate at later times, similar to the in vitro infection $(6,9,15,28,29)$, has been questioned by other studies showing instead direct correlation between the two mRNA species during the whole course of the disease $(13,16)$. Some of the still unresolved issues (and discrepancies) in the results obtained by the above mentioned studies are possibly due to the different methods used for the quantification of HIV nucleic acids in infected samples. In fact, these measurements are often possibly hindered by the poor quantitative outcome of conventional PCR amplification.

1. Abbreviations used in this paper: LTNP, long-term nonprogressor; PBMC, peripheral blood mononuclear cell; RT-PCR, reverse transcriptase-PCR. 
In recent years, we have developed and extensively applied a competitive PCR technology for the exact quantitation of low abundance nucleic acids in clinical samples (30-35), including HIV DNA and RNA in different clinical settings (3641). Competitive PCR and RT-PCR (using internal DNA and RNA competitors, respectively) couple the sensitivity of conventional PCR to the accuracy that is necessary for the exact quantification of the target molecules, irrespective of sample nucleic acid purity, primer pair efficiency and specificity, or amplification kinetics profile. In particular, we have recently developed a multicompetitive procedure for the quantification of several virologic parameters in samples from HIV-infected patients, including viremia, levels of provirus DNA, and different classes of HIV mRNAs in infected cells (37). This procedure also allows the exact standardization of the proviral DNA levels to the copy number of the $\beta$-globin gene, and those of the viral mRNAs to the levels of the ubiquitously expressed $\beta$-actin gene mRNA.

To understand the role of the regulation of virus gene expression in the progression of the disease, we have now determined the above mentioned quantitative virologic parameters in 11 patients with nonprogressive HIV infection. These patients fit the definition of long term nonprogressors (LTNPs), as they belong to the small subset of HIV-1-infected persons (5-8\% of the total) who tolerate infection without immunosuppression of disease for prolonged periods (42-47). The study of the immunologic features of these individuals and of the properties of their viral strains holds great promise for the understanding of the cellular and molecular correlates that de- termine disease progression. In occasional cases, defective viruses have been detected from LTNPs $(48,49)$; in other studies, these individuals were found to be characterized by the presence of robust cellular and humoral immune responses against HIV (50-53). In all cases, the most prominent feature of these individuals is the presence of a highly diminished viral load.

At present, the kinetics of replication of HIV-1 in the lymphoid cells of these individuals, with particular reference to the mechanisms controlling virus gene expression at the transcriptional and posttranscriptional levels, is still unexplored.

\section{Methods}

Patients. HIV-1-infected individuals were selected among the patients followed at the Division of Medical Oncology and AIDS, Centro di Riferimento Oncologico. LTNP patients were defined as individuals having documented HIV-1 infection for $\geq 7 \mathrm{yr}, \mathrm{CD} 4+$ cell counts of $>500$ cells $/ \mathrm{mm}^{3}$ and/or $>30 \%$, without any decline $>15 \%$ during this time period, and no symptoms related to HIV-1 infection. None of these patients had ever received antiretroviral therapy. Of the 11 LTNPs included in this study, 9 had been infected for $\geq 9 \mathrm{yr}$ (Table I). The LTNP group was contrasted with a matched group of immunologic progressors, defined as patients having documented HIV-1 infection for $\geq 7 \mathrm{yr}$, with a CD4+ cell count $\geq 500 / \mathrm{mm}^{3}$ and/or $>30 \%$ at the time of diagnosis and with the occurrence of an AIDSdefining condition not before $7 \mathrm{yr}$ from this time. These patients did not receive antiretroviral therapy for at least $4 \mathrm{wk}$ before sampling. The disease stage and the CD4+ cell counts of these patients at the time of the study are shown in Table I.

Table I. Clinical and Laboratory Characteristics of the Patients Included in the Study

\begin{tabular}{|c|c|c|c|c|c|c|c|}
\hline Patient & Age (yr) & Sex & Route of infection & No. of $\mathrm{CD} 4$ cells $/ \mathrm{mm}^{3}$ & No. of years infected & HIV disease stage & p24 antigen $(\mathrm{pg} / \mathrm{ml})$ \\
\hline $\mathrm{N} 1$ & 37 & $\mathrm{~F}$ & IVDU & 538 & 10 & A1 & NS \\
\hline $\mathrm{N} 2$ & 25 & $\mathrm{~F}$ & IVDU & 1819 & 7 & A1 & NS \\
\hline N3 & 32 & $\mathrm{~F}$ & Hetero & 946 & 9 & A1 & NS \\
\hline $\mathrm{N} 4$ & 31 & $\mathrm{M}$ & IVDU & 838 & 9 & A1 & NS \\
\hline N5 & 35 & M & IVDU & 740 & 10 & A1 & NS \\
\hline N6 & 36 & $\mathrm{M}$ & Homo & 673 & 7 & A1 & NS \\
\hline N7 & 29 & M & IVDU & 685 & 9 & A1 & NS \\
\hline N8 & 35 & $\mathrm{~F}$ & Hetero & 611 & 10 & A1 & NS \\
\hline N9 & 34 & $\mathrm{M}$ & IVDU & 858 & 9 & A1 & NS \\
\hline N10 & 31 & $\mathrm{M}$ & IVDU & 900 & 10 & A1 & NS \\
\hline N11 & 34 & $\mathrm{M}$ & IVDU & 650 & 9 & A1 & NS \\
\hline $\mathrm{P} 1$ & 32 & $\mathrm{~F}$ & IVDU & 216 & 10 & $\mathrm{C} 2$ & NS \\
\hline $\mathrm{P} 2$ & 35 & $\mathrm{~F}$ & Hetero & 14 & 9 & $\mathrm{C} 3$ & NS \\
\hline $\mathrm{P} 4 *$ & 42 & $\mathrm{M}$ & Homo & 29 & 9 & $\mathrm{C} 3$ & 77.6 \\
\hline P5 & 38 & $\mathrm{~F}$ & IVDU & 24 & 10 & $\mathrm{C} 3$ & $>100$ \\
\hline P6 & 36 & $\mathrm{M}$ & IVDU & 156 & 10 & $\mathrm{C} 3$ & NS \\
\hline P7 & 35 & $\mathrm{~F}$ & IVDU & 88 & 10 & $\mathrm{C} 2$ & 28.8 \\
\hline P8 & 35 & $\mathrm{M}$ & IVDU & 17 & 7 & $\mathrm{C} 3$ & $>100$ \\
\hline P9 & 37 & $\mathrm{M}$ & IVDU & 37 & 9 & $\mathrm{C} 3$ & 47 \\
\hline P10 & 32 & $\mathrm{M}$ & IVDU & 12 & 8 & $\mathrm{C} 3$ & $>100$ \\
\hline $\mathrm{P} 10^{*}$ & 28 & $\mathrm{M}$ & IVDU & 2 & 8 & C3 & $>100$ \\
\hline P11 & 32 & $\mathrm{M}$ & IVDU & 18 & 10 & $\mathrm{C} 3$ & NS \\
\hline $\mathrm{P} 12$ & 40 & $\mathrm{M}$ & IVDU & 80 & 7 & $\mathrm{C} 3$ & NS \\
\hline
\end{tabular}

N1-N11, nonprogressors; P1-P12, progressors. IVDU, IV drug use; homo, homosexual; hetero, heterosexual. HIV disease staging is according to the Centers For Disease Control 1992 classification. 
DNA and RNA extraction. PBMCs were obtained by FicollHypaque gradient centrifugation from $10 \mathrm{ml}$ of EDTA-collected blood. DNA was extracted from frozen cellular pellets according to standard procedures (54). Viral RNA was extracted from the virion pellet obtained after ultracentrifugation $(40,000 \mathrm{rpm}$ on an SW41t rotor for $60 \mathrm{~min}$; Beckman Instruments, Fullerton, CA) of $5 \mathrm{ml}$ plasma $(38,40)$, according to the guanidinium thiocyanate procedure (55). Cellular RNA was extracted from frozen cellular pellets by cell lysis in solution $\mathrm{D}$ according to the guanidinium thiocyanate procedure (55).

Primers and competitor. Plasmid pSPLI-II was used as a competitor for the competitive PCR determination of the copy number of HIV-1 proviral DNA and of the reference single-copy $\beta$-globin gene in DNA samples, while the in vitro transcription product from plasmid pSPLI-II was used for the RT-PCR quantification of HIV-1 genomic RNA in serum, of HIV-1 viral mRNAs, and of the cellular $\beta$-actin mRNA in cellular RNA samples. The construction (37) and the use $(38,40)$ of this multicompetitor plasmid for the quantitation of HIV-1 nucleic acids have already been described; a schematic representation of the insert of this plasmid is shown in Fig. $1 \mathrm{~B}$. Briefly, this insert contains four HIV-1 oligonucleotide sequences (primers 1, 2II, 3, and 5) arranged to produce amplification products that are different in size (and hence recognizable by resolution by polyacrylamide gel electrophoresis) from those deriving from the viral templates. Primer 1 (nucleotides 246-273 of the hivlai; Los Alamos National Laboratory file, Los Alamos, NM) is localized immediately downstream of the 5' LTR sequence, primer 2II (nucleotides 463438 ) at the $5^{\prime}$ end of the gag gene, and primer 5 (nucleotides 8021$8000)$ at a $3^{\prime}$ position with respect to the $3^{\prime}$-most splice acceptor site of the HIV-1 full length mRNA (Fig. $1 A$ ). Amplification with primer pair 1-2II detects HIV-1 proviral DNA in infected cell DNA samples, unspliced viral mRNAs on cellular mRNA samples, and HIV-1 genomic RNA on virion RNA samples. Amplification with primer pair 1-5 detects multispliced HIV-1 mRNAs in cellular RNA samples.

Additionally, plasmid pSPLI-II also contains two competitor segments for cellular $\beta$-actin mRNA (32) and $\beta$-globin DNA (31) copy number determination, using primer pairs $\mathrm{PCO} 3$ and $\mathrm{PCO} 4$, and BA1 and BA4, respectively. These competitor segments contain a perfect match to the respective target sequences, except for the addition of 20 extra bp in the middle.

For the DNA competition experiments, a preparation of plasmid pSPLI-II was accurately quantified by spectrophotometry, linearized by digestion at the KpnI site, and an aliquot was diluted and directly used as a competitive template.

For the competitive RNA experiments, the competitor RNA was obtained by in vitro run-off transcription from $50 \mathrm{ng}$ of plasmid pSPLI-II after linearization with KpnI. The in vitro transcription reaction was performed using a T7 RNA polymerase-based commercial kit (Promega Corp., Madison, WI), with the addition of $2 \mu \mathrm{l}\left[{ }^{32} \mathrm{P}\right] \mathrm{UTP}$ $(3,000 \mathrm{Ci} / \mathrm{mmol}, 10 \mathrm{mCi} / \mathrm{ml}$; Amersham International, Little Chalfont, UK) to the reaction mix, corresponding to $2.07 \times 10^{7} \mathrm{cpm}$, as experimentally evaluated by Cerenkov counting. After completion of the transcription reaction, the template DNA was removed by DNase I digestion followed by purification of the newly synthesized RNA by denaturing polyacrylamide gel electrophoresis and elution from the gel. An aliquot of the purified competitor RNA preparation was measured in a $\beta$ counter and, according to the $U$ content of the transcript, its concentration was evaluated from the final specific activity, as already described $(32,33)$.

Competitive PCR and RT-PCR. Competitive PCR for the quantification of HIV-1 and $\beta$-globin gene copy number was carried out on $1 \mu \mathrm{l}$ of sample DNA with the addition of increasing concentrations of the pSPLI-II competitive template, in $100 \mu \mathrm{l}$ of PCR buffer (50 $\mathrm{mM} \mathrm{KCl}, 10 \mathrm{mM}$ Tris- $\mathrm{HCl}, 2 \mathrm{mM} \mathrm{MgCl}$ ) containing the two primers (100 pmol each), the four dNTPs $(200 \mu \mathrm{M}$ each), and $2.5 \mathrm{U}$ of Taq DNA polymerase (Perkin-Elmer Cetus Instruments, Emeryville, CA). Samples were submitted to 50 cycles of amplification with the following cycle profile: denaturation at $95^{\circ} \mathrm{C}$ for $30 \mathrm{~s}$, annealing at $60^{\circ} \mathrm{C}$ (for both primer sets 1-2II and $\beta$-globin) for $30 \mathrm{~s}$, and extension at $72^{\circ} \mathrm{C}$ for $30 \mathrm{~s}$. Before PCR analysis, DNA samples and KpnI-digested linearized pSPLI-II competitor were heated to $95^{\circ} \mathrm{C}$ for $5 \mathrm{~min}$ to ensure complete denaturation.

For the RNA quantification experiments, the extracted RNA was reverse transcribed in the presence of the antisense oligonucleotides specific for each class of transcripts. Each reaction contained $1 \mu \mathrm{l}$ of test RNA sample and $3 \mu \mathrm{l}$ of RNA competitor (the pSPLI-II in vitro transcription product, opportunely diluted) in $20 \mu \mathrm{l}$ of reverse transcription mix, composed of $75 \mathrm{mM} \mathrm{KCl}, 50 \mathrm{mM}$ Tris- $\mathrm{HCl}, \mathrm{pH} 8.3,3 \mathrm{mM}$ $\mathrm{MgCl}_{2}, 0.4 \mathrm{mM}$ each dNTP (Pharmacia LKB Biotechnology, Uppsala, Sweden), $2 \mathrm{mM}$ antisense primer, $400 \mathrm{U}$ MMLV-RT (Promega Corp.), $20 \mathrm{U}$ RNasin (Promega Corp.). RNA was preheated at $65^{\circ} \mathrm{C}$ for $5 \mathrm{~min}$ and incubated with the reaction mix at $37^{\circ} \mathrm{C}$. After $1 \mathrm{~h}$, the reaction was stopped by incubation at $95^{\circ} \mathrm{C}$ for $5 \mathrm{~min}$ and samples were cooled on ice. The $20-\mu l$ reverse transcription reaction was then diluted in PCR buffer to a final volume of $100 \mu \mathrm{l}$, containing 100 pmol both primers, $200 \mu \mathrm{M}$ of the four dNTPs each, and $2.5 \mathrm{U}$ of Taq DNA polymerase. Samples were submitted to 50 cycles of amplification with the following cycle profiles: denaturation at $95^{\circ} \mathrm{C}$ for $30 \mathrm{~s}$, annealing at $60^{\circ} \mathrm{C}$ (primer sets 1-2II, 1-5, and $\beta$-actin) for $30 \mathrm{~s}$, extension at $72^{\circ} \mathrm{C}$ for $30 \mathrm{~s}$.

After amplification, $15 \mu \mathrm{l}$ of each PCR product were resolved on an $8 \%$ nondenaturing polyacrylamide gel, visualized under ultraviolet light after ethidium bromide staining and photographed. Quantification of the amplification product was obtained by densitometric scanning of the ethidium bromide-stained gels.

Statistical analyses. Statistical analyses were done using the StatView 4.5 statistical software package for the Macintosh (Abacus Concepts, Inc., Berkeley, CA).

\section{Results}

11 individuals with long term nonprogressive HIV infection (LTNPs; see Methods for definition) were included in this study. Some of the clinical and immunological features of these individuals are reported in Table I, including age (mean age: $32 \mathrm{yr}$ ), sex, and probable route of infection. They had an average time of documented infection of $9.0 \mathrm{yr}$ (range 7-10 yr), and mean CD4+ cells count of 841.6 cells $/ \mathrm{mm}^{3}$ (SD 348.6 cells). A detailed analysis of the immunological profile and of this group of LTNPs has already been presented elsewhere (56). Here, we describe the quantitative virologic features of HIV infection in these individuals, and contrast them with those found in 12 matched patients (Table I) having the same age and the same period of documented HIV infection (mean $8.9 \mathrm{yr}$, range 7-10 yr) and with clear progression of the disease (CD4+ cell counts: mean 57.7 cells $/ \mathrm{mm}^{3}$, SD 66.6 cells). Several quantitative virologic parameters (including viremia, proviral DNA copy number, and levels of unspliced and multispliced mRNAs in peripheral blood mononuclear cells, as schematically shown in Fig. $1 C$ ) were determined in these patients by a multiple competitive PCR procedure (37). By taking advantage of the use of a single multicompetitor molecule, this procedure permits the exact quantification of the relative abundance of different DNA and RNA species. The competitor for these quantifications is plasmid pSPLI-II (Fig. $1 \mathrm{~B}$ ) acting as a competitive template for the determination of HIV-1 proviral DNA and cellular $\beta$-globin gene copy numbers in DNA samples, and its in vitro transcription product, allowing the quantification of HIV-1 unspliced, single-spliced, and unspliced HIV-1 transcripts and of cellular $\beta$-actin mRNA in cellular mRNA samples. Quantification of multispliced transcripts is performed by using the prevalent transcript coding 


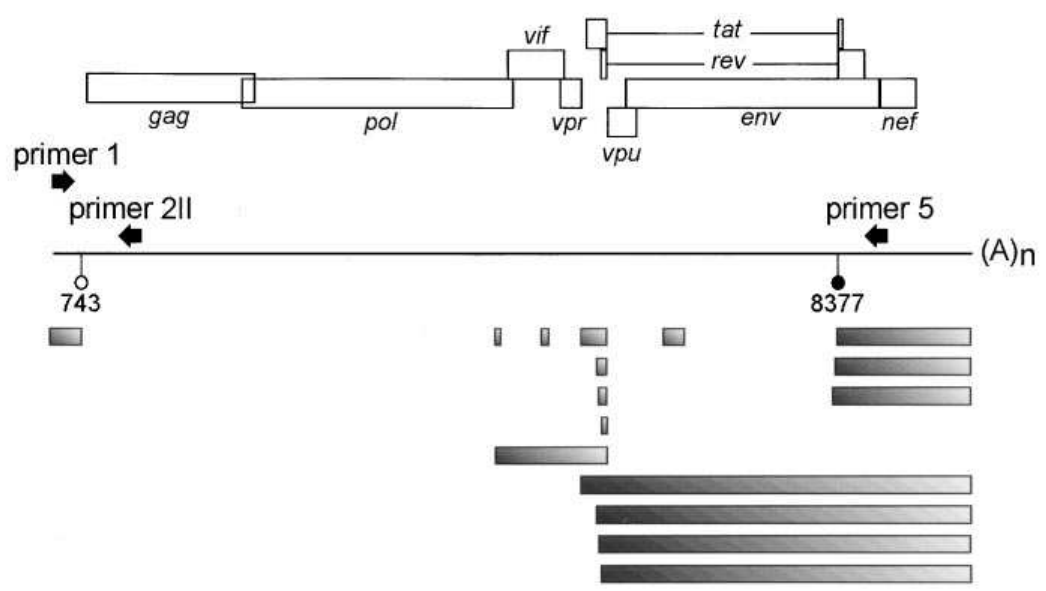

B
Figure 1. Competitive PCR and RT-PCR for the quantification of HIV-1 nucleic acids. ( $A$ ) HIV gene organization (top), primary mRNA (middle), and HIV exons (grayshadowed boxes, bottom). The 5' most splice site at position 743 and the $3^{\prime}$ most splice site at position 8377 are indicated by white and black dots, respectively. Numbering is according to file $h x b 2 c g$ of the LANL data bank of AIDS-related nucleic acid sequences (60). The position of the three HIV-specific oligonucleotides used in this study and their orientation are shown. These oligonucleotides were selected on the basis of their high level of sequence homology with most HIV isolates in the LANL data base. (B) Schematic representation of the insert of plasmid pSPLI-II, used as competitor for the competitive PCR experiments. The plasmid contains three DNA fragment inserts, to be used as competitors for the determination of HIV-1, $\beta$-actin, and $\beta$-globin copy number. The HIV-1 insert contains four HIV-1 primers $(1,5,2 \mathrm{II}$, and 3 , indicated by arrows showing the orientation); amplification with primers 1 and 2II detects proviral DNA in DNA samples and viral unspliced genomic RNA in RNA samples. The positions of

these primers on the competitor are arranged to produce a 240-bp amplification fragment that can be easily resolved by size from the corresponding HIV-1 PCR products. The $\beta$-globin fragment contains a segment of the human $\beta$-globin gene with 20 extra nucleotides in the middle (31), amplifiable with primers PCO3 and PCO4 to give rise to a product of $130 \mathrm{bp}$. The RNA competitor for the competitive RT-PCR experiments is obtained by in vitro run off transcription of this plasmid by T7 RNA polymerase after linearization at the KpnI site. The transcribed RNA contains a polyA tail, indicated by (A) at its $3^{\prime}$ end. (C) Flow chart for the quantification of quantitative virologic parameters in HIV-1infected individuals. Quantitative PCR was performed on DNA samples extracted from PBMCs with linearized pSPLI-II plasmid DNA competitor and primer sets 1-2II (HIV) and PCO3-PCO4 ( $\beta$-globin). Competitive RT-PCR was performed on RNA samples using the in vitro transcription product of pSPLI-II and primer sets 1-2II (viremia in plasma RNA samples and genomic length mRNA in cellular samples), 1-5 (multispliced Rev mRNA in cellular samples), and BA1-BA4 ( $\beta$-actin in cellular samples). In all cases, a fixed amount of sample DNA or RNA was mixed with increasing amounts of DNA or RNA competitor, respectively, and submitted to PCR or RT-PCR. After amplification, the PCR products were resolved by polyacrylamide gel electrophoresis, stained by ethidium bromide, and the bands corresponding to the PCR products for the competitor and the template were quantified by densitometric scanning. The ratio between competitor and target (shown at the bottom of the gels for the lanes where both the species were detectable) reflects the ratio between the two species at the beginning of the reaction. M, molecular weight marker; molec., molecules. Arrows indicate HIV-specific bands; in the case of multispliced transcripts, several products are detectable; the one used for quantification corresponds to a cDNA coding for Rev (see reference 37).

for the Rev protein as an estimate for all the transcripts in this class. The use of internal standards for the quantification of total extracted DNA ( $\beta$-globin) and RNA ( $\beta$-actin) appears very important for these quantitative evaluations, since the total amount of extracted nucleic acids from clinical samples is often very variable. We have already used this procedure to study the regulation of HIV-1 gene expression in in vitro-infected experimental models (37) and to monitor viral load in HIV-1infected patients $(38,40,41)$.

Viral load. The levels of HIV-1 viremia were determined by competitive RT-PCR amplification of RNA extracted from virion pellets using the in vitro-transcribed RNA product of plasmid pSPLI-II and primer set 1-2II (Fig. $1 A$ ). The values obtained are reported in Table II, where they are expressed as viral RNA molecules per milliliter of plasma. The distribution of these values in the two categories of patients is graphically shown in Fig. $2 A$. The threshold for detection by competitive RT-PCR was of one molecule in $25 \mu \mathrm{l}$ of extracted RNA (corresponding to 40 viral RNA molecules per milliliter). Viral RNA resulted at undetectable levels in four patients with nonprogressive infection; these samples are indicated by an arrow pointing down in Fig. $2 \mathrm{~A}$. For statistical analysis, HIV RNA concentration in the samples was considered $10 \times$ less abundant than the threshold limit, considering that $a<10$-fold difference between competitor and sample would have been detected in the competitive PCR assay $(30,33)$. 


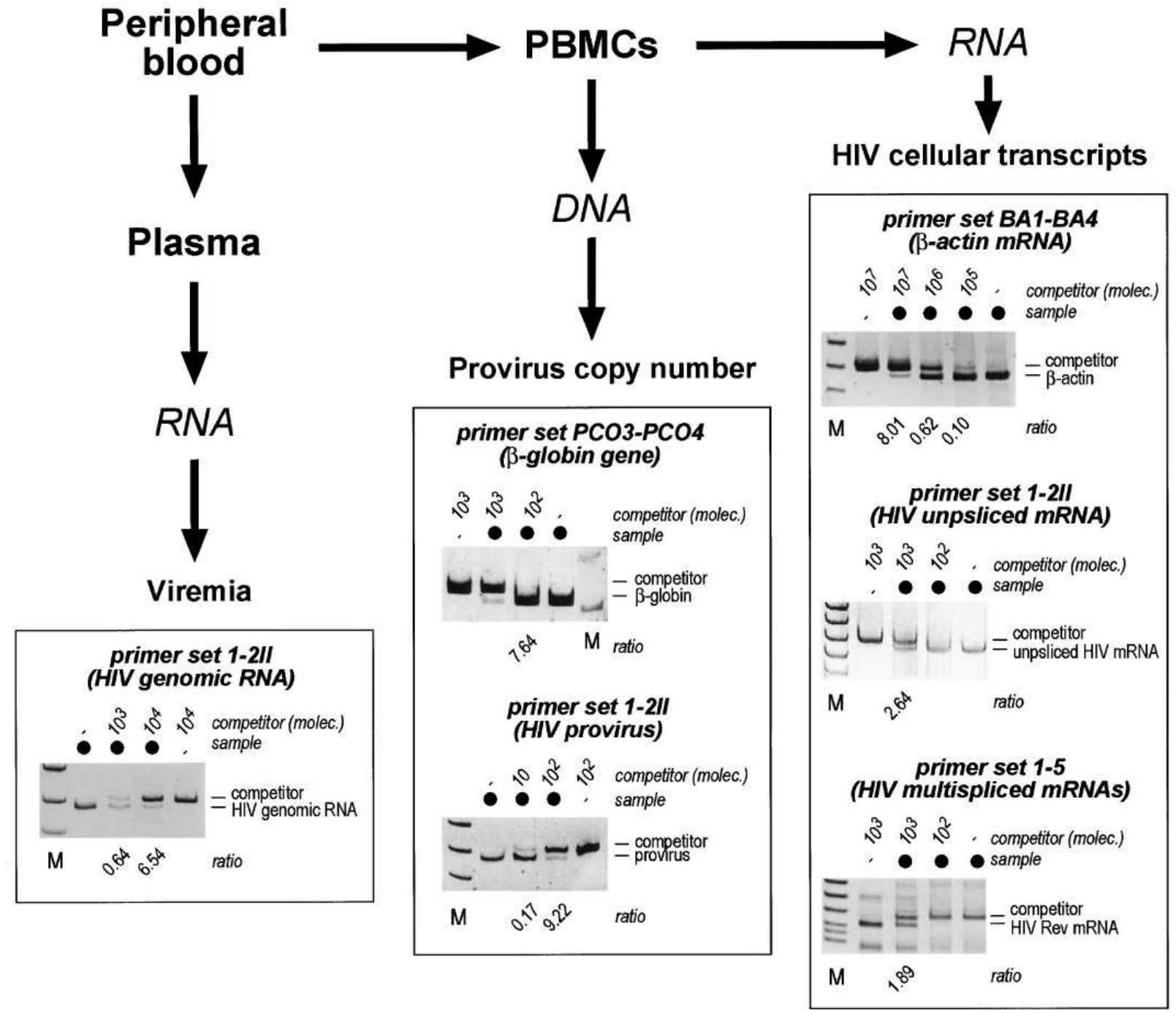

Figure 1 (Continued)

The mean levels of virion-associated RNA in patients with nonprogressive infection was of $5.82 \times 10^{2}$ molecules $/ \mathrm{ml}$ plasma (range, $\min / \max : 4 / 2.5 \times 10^{3}$; SD $8.85 \times 10^{2}$ ). These values were several orders of magnitude lower than those detected in the group of patients with progressive HIV infections (mean value, $1.97 \times 10^{6}$ viral RNA molecules $/ \mathrm{ml}$; range, $5 \times$ $10^{3} / 2 \times 10^{7} ;$ SD $5.47 \times 10^{6} ; P<0.0001$ in the Mann-Whitney nonparametric test for unpaired groups).

The amount of HIV-1 proviral DNA copies in PBMCs from the two groups of patients was determined by the quantification of viral DNA and of the $\beta$-globin cellular DNA copy numbers in extracted DNA samples. Proviral DNA copy numbers are reported in Table II, where they are expressed as relative to the total number of mononuclear cells (as evaluated by $\beta$-globin gene quantification) or by taking into account also the number of circulating CD4+ cells, considering that these cells are the targets for HIV infection. The distribution of HIV provirus DNA in CD4+ cells is shown in Fig. $2 B$ for the two groups of patients. The mean value of proviral DNA copies in CD4+ cells from nonprogressor patients was of 0.012 mole-
cules/CD4+ cell, SD 0.019; range 0.001-0.066), corresponding to 1 provirus for every $83 \mathrm{CD} 4+$ cells. In progressor patients, the mean value of provirus DNA copies was of 4.00 molecules per CD4+ cell (SD 5.08; range 0.2-15; $P<0.0001$ ). This estimate indicates that virtually all the circulating CD4+ cells harbor HIV viral genomes in patients with progressed infection. It should be observed that the quantification of HIV provirus by the selected primers detects both integrated and episomal DNA.

Taken together, the data obtained by the quantification of the levels of viremia and of provirus copy number in PBMCs support the notion that viral load is highly augmented in patients progressing toward overt HIV disease. Paired comparison of the levels of viremia and of the provirus copy number in the total sample population shows that these two measurements are very well correlated (nonparametric Spearman rank correlation test, $P<0.001)$. Thus, the combined use of these two variables depicts two distinct patient populations (progressor and nonprogressor) clearly distinguishable by different viral load. 
Table II. HIV-1 DNA and RNA Levels in Nonprogressor and Progressor Individuals

\begin{tabular}{|c|c|c|c|c|c|c|c|c|c|c|}
\hline \multirow[b]{2}{*}{ Patient } & \multirow{2}{*}{$\begin{array}{c}\text { Viremia } \\
\text { HIV RNA/ml plasma }\end{array}$} & \multicolumn{2}{|c|}{ Proviral DNA } & \multicolumn{3}{|c|}{ Spliced HIV RNA } & \multicolumn{3}{|c|}{ Unspliced HIV RNA } & \multirow[b]{2}{*}{ Spliced/unspliced HIV RNA } \\
\hline & & HIV DNA/ß-globin & HIV DNA/CD4 & HIV RNA/ $\beta$-actin & HIV RNA/CD4 & HIV RNA/provirus & HIV RNA/ $\beta$-actin & HIV RNA/CD4 & HIV RNA/provirus & \\
\hline N1 & $8.3 \times 10^{1}$ & $3.0 \times 10^{-2}$ & $6.6 \times 10^{-2}$ & $2.0 \times 10^{-4}$ & $4.4 \times 10^{-4}$ & $6.7 \times 10^{-3}$ & $2.0 \times 10^{-4}$ & $4.4 \times 10^{-4}$ & $6.7 \times 10^{-3}$ & $1.0 \times 10^{0}$ \\
\hline $\mathrm{N} 2$ & $8.3 \times 10^{2}$ & $3.0 \times 10^{-3}$ & $7.3 \times 10^{-3}$ & $1.0 \times 10^{-4}$ & $2.4 \times 10^{-4}$ & $3.3 \times 10^{-2}$ & $3.3 \times 10^{-4}$ & $8.1 \times 10^{-4}$ & $1.1 \times 10^{-1}$ & $3.0 \times 10^{-1}$ \\
\hline N3 & $7.5 \times 10^{2}$ & $2.4 \times 10^{-3}$ & $5.3 \times 10^{-3}$ & $1.0 \times 10^{-3}$ & $2.2 \times 10^{-3}$ & $4.2 \times 10^{-1}$ & $1.0 \times 10^{-2}$ & $2.2 \times 10^{-2}$ & $4.2 \times 10^{0}$ & $1.0 \times 10^{-1}$ \\
\hline N4 & $2.0 \times 10^{2}$ & $1.0 \times 10^{-3}$ & $2.2 \times 10^{-3}$ & $1.7 \times 10^{-5}$ & $3.7 \times 10^{-5}$ & $1.7 \times 10^{-2}$ & $6.0 \times 10^{-5}$ & $1.3 \times 10^{-4}$ & $6.0 \times 10^{-2}$ & $2.8 \times 10^{-1}$ \\
\hline N5 & $2.5 \times 10^{3}$ & $5.0 \times 10^{-3}$ & $1.6 \times 10^{-2}$ & $8.3 \times 10^{-5}$ & $2.7 \times 10^{-4}$ & $1.7 \times 10^{-2}$ & $5.0 \times 10^{-4}$ & $1.6 \times 10^{-3}$ & $1.0 \times 10^{-1}$ & $1.7 \times 10^{-1}$ \\
\hline N6 & $1.3 \times 10^{1}$ & $2.5 \times 10^{-3}$ & $6.0 \times 10^{-3}$ & $5.0 \times 10^{-5}$ & $1.2 \times 10^{-4}$ & $2.0 \times 10^{-2}$ & $1.0 \times 10^{-4}$ & $2.4 \times 10^{-4}$ & $4.0 \times 10^{-2}$ & $5.0 \times 10^{-1}$ \\
\hline N7 & $4.0 \times 10^{0}$ & $1.0 \times 10^{-3}$ & $2.7 \times 10^{-3}$ & $1.0 \times 10^{-4}$ & $2.7 \times 10^{-4}$ & $1.0 \times 10^{-1}$ & $4.0 \times 10^{-3}$ & $1.1 \times 10^{-2}$ & $4.0 \times 10^{0}$ & $2.5 \times 10^{-2}$ \\
\hline N8 & $4.0 \times 10^{0}$ & $1.2 \times 10^{-3}$ & $2.8 \times 10^{-3}$ & $2.5 \times 10^{-4}$ & $5.8 \times 10^{-4}$ & $2.1 \times 10^{-1}$ & $2.5 \times 10^{-5}$ & $5.8 \times 10^{-5}$ & $2.1 \times 10^{-2}$ & $1.0 \times 10^{1}$ \\
\hline N9 & $5.0 \times 10^{0}$ & $4.0 \times 10^{-4}$ & $9.3 \times 10^{-4}$ & $3.3 \times 10^{-4}$ & $7.7 \times 10^{-4}$ & $8.3 \times 10^{-1}$ & $2.0 \times 10^{-3}$ & $4.6 \times 10^{-3}$ & $5.0 \times 10^{0}$ & $1.7 \times 10^{-1}$ \\
\hline $\mathrm{N} 10$ & $2.0 \times 10^{3}$ & $1.0 \times 10^{-2}$ & $2.5 \times 10^{-2}$ & $4.0 \times 10^{-3}$ & $1.0 \times 10^{-2}$ & $4.0 \times 10^{-1}$ & $2.0 \times 10^{-3}$ & $5.0 \times 10^{-3}$ & $2.0 \times 10^{-1}$ & $2.0 \times 10^{0}$ \\
\hline N11 & $4.0 \times 10^{0}$ & $5.0 \times 10^{-4}$ & $1.9 \times 10^{-3}$ & ND & - & - & ND & - & - & - \\
\hline $\mathrm{P} 1$ & $1.2 \times 10^{5}$ & $3.3 \times 10^{-1}$ & $5.6 \times 10^{0}$ & $5.0 \times 10^{-3}$ & $8.3 \times 10^{-2}$ & $1.5 \times 10^{-2}$ & $1.5 \times 10^{-1}$ & $2.5 \times 10^{0}$ & $4.5 \times 10^{-1}$ & $3.3 \times 10^{-2}$ \\
\hline $\mathrm{P} 2$ & $2.0 \times 10^{7}$ & $3.3 \times 10^{-1}$ & $1.2 \times 10^{1}$ & $1.0 \times 10^{-4}$ & $3.7 \times 10^{-3}$ & $3.0 \times 10^{-4}$ & $2.5 \times 10^{-2}$ & $9.3 \times 10^{-1}$ & $7.5 \times 10^{-2}$ & $4.0 \times 10^{-3}$ \\
\hline $\mathrm{P} 4 *$ & $1.2 \times 10^{5}$ & $5.0 \times 10^{-2}$ & $8.6 \times 10^{-1}$ & $5.0 \times 10^{-3}$ & $8.6 \times 10^{-2}$ & $1.0 \times 10^{-1}$ & $4.0 \times 10^{-1}$ & $6.9 \times 10^{0}$ & $8.0 \times 10^{0}$ & $1.3 \times 10^{-2}$ \\
\hline P5 & $5.0 \times 10^{4}$ & ND & - & $2.5 \times 10^{-3}$ & $3.0 \times 10^{-2}$ & $\bullet$ & $3.0 \times 10^{-2}$ & $3.6 \times 10^{-1}$ & $\bullet$ & $8.3 \times 10^{-1}$ \\
\hline P6 & $1.0 \times 10^{6}$ & $7.5 \times 10^{-2}$ & $6.4 \times 10^{-1}$ & $7.5 \times 10^{-4}$ & $6.4 \times 10^{-3}$ & $1.0 \times 10^{-2}$ & $1.5 \times 10^{0}$ & $1.3 \times 10^{1}$ & $2.0 \times 10^{1}$ & $5.0 \times 10^{-4}$ \\
\hline P7 & $3.0 \times 10^{5}$ & $2.8 \times 10^{-1}$ & $1.6 \times 10^{0}$ & $2.0 \times 10^{-3}$ & $1.1 \times 10^{-2}$ & $7.3 \times 10^{-3}$ & $1.0 \times 10^{-1}$ & $5.7 \times 10^{-1}$ & $3.6 \times 10^{-1}$ & $2.0 \times 10^{-2}$ \\
\hline P8 & $6.0 \times 10^{5}$ & $3.0 \times 10^{-1}$ & $1.9 \times 10^{0}$ & $6.3 \times 10^{-4}$ & $4.0 \times 10^{-3}$ & $2.1 \times 10^{-2}$ & $1.0 \times 10^{-1}$ & $6.4 \times 10^{-1}$ & $3.3 \times 10^{-1}$ & $6.2 \times 10^{-2}$ \\
\hline P9 & $6.0 \times 10^{5}$ & $5.0 \times 10^{-2}$ & $4.7 \times 10^{-1}$ & $5.0 \times 10^{-4}$ & $4.7 \times 10^{-3}$ & $1.0 \times 10^{-2}$ & $5.0 \times 10^{-1}$ & $4.7 \times 10^{0}$ & $1.0 \times 10^{1}$ & $1.0 \times 10^{-3}$ \\
\hline $\mathrm{P} 10$ & $6.7 \times 10^{4}$ & $1.0 \times 10^{-1}$ & $4.0 \times 10^{0}$ & $3.0 \times 10^{-3}$ & $1.2 \times 10^{-1}$ & $3.0 \times 10^{-2}$ & ND & - & - & - \\
\hline $\mathrm{P} 10^{*}$ & $5.0 \times 10^{3}$ & $7.5 \times 10^{-2}$ & $1.5 \times 10^{1}$ & $1.0 \times 10^{-3}$ & $2.0 \times 10^{-1}$ & $1.3 \times 10^{-2}$ & $5.0 \times 10^{-2}$ & $1.0 \times 10^{1}$ & $6.7 \times 10^{-1}$ & $2.0 \times 10^{-2}$ \\
\hline P11 & $2.5 \times 10^{5}$ & $4.0 \times 10^{-2}$ & $2.0 \times 10^{-1}$ & $1.2 \times 10^{-4}$ & $6.0 \times 10^{-4}$ & $3.0 \times 10^{-3}$ & $4.0 \times 10^{-1}$ & $2.0 \times 10^{0}$ & $1.0 \times 10^{1}$ & $3.0 \times 10^{-4}$ \\
\hline $\mathrm{P} 12$ & $5.0 \times 10^{5}$ & $3.0 \times 10^{-1}$ & $1.5 \times 10^{0}$ & ND & - & - & $1.3 \times 10^{-2}$ & $6.7 \times 10^{-2}$ & $4.0 \times 10^{-1}$ & - \\
\hline
\end{tabular}

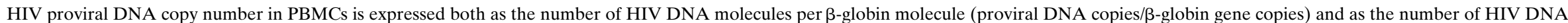

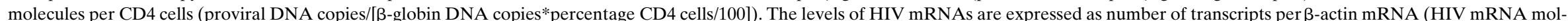

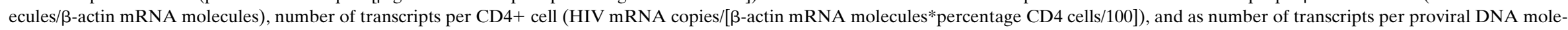

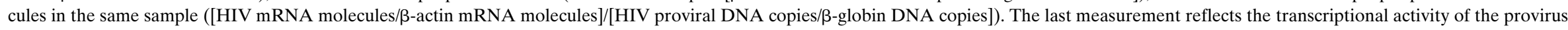
(i.e., number of transcripts produced per provirus). The last column reports the ratio between spliced and unspliced transcripts. 


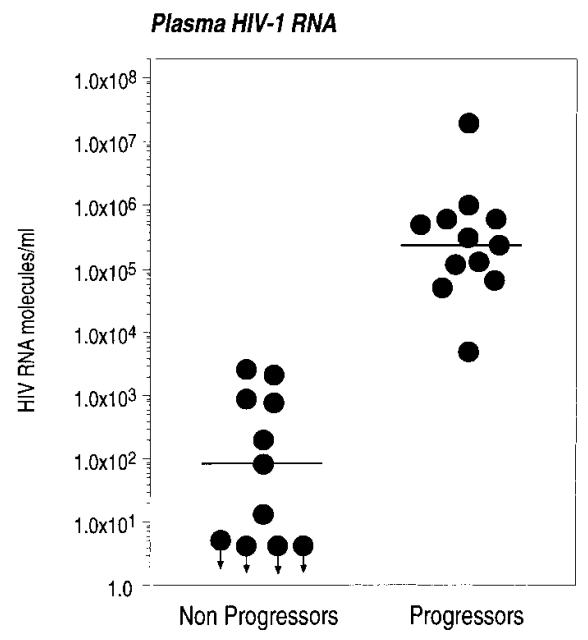

B

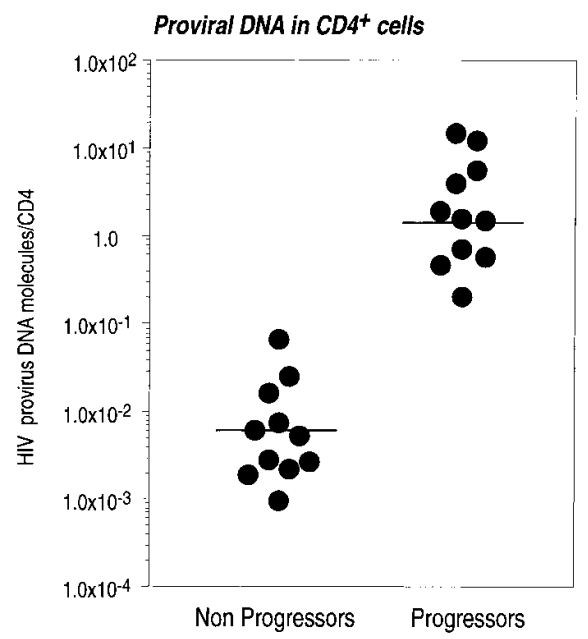

Figure 2. Viral load. (A) Viral genomic RNA molecules per milliliter of plasma (viremia) in patients with nonprogressive or progressive HIV-1 infection. Viral RNA results were undetectable in four patients with nonprogressive infection; these samples are indicated by an arrow pointing down. The median of the values for each group is indicated. (B) Proviral DNA copy number in peripheral blood CD4+ cells. The values represent the number of provirus DNA molecules per CD4+ cell, evaluated by considering the total number of cells (according to the quantification of the $\beta$-globin gene copy number) and the percentage of CD4+ cells. The actual measurements are shown in Table II.
Expression of viral $m R N A$ s. The finding that viral load is highly increased in patients progressing in HIV disease with respect to nonprogressing individuals $(>3,000 \times$ for viremia and $>400 \times$ for provirus copy number) predicts an increased rate of virus replication in the former group of patients. This should be reflected by the presence of an increased number of virus-specific transcripts in cellular RNA samples. Therefore, we quantitatively determined the levels of viral mRNAs belonging to the unspliced and multispliced classes in cellular RNA samples obtained from peripheral blood cells from the two groups of patients. The results are presented in Table II, where the measurements of two transcript classes are expressed as relative to $\beta$-actin mRNA levels (i.e., viral RNAs in the total RNA sample), or are expressed as relative to the expected $\beta$-actin mRNA levels in CD4+ cells only (first two columns for each transcript class). The latter measurements are graphically shown in Fig. 3, $A$ and $B$, respectively.

The levels of both HIV multispliced and unspliced transcripts were clearly higher in progressor patients. The mean value for short transcripts was $1.5 \times 10^{-3}$ Rev mRNA molecules/ $\beta$-actin molecule in nonprogressors $\left(\mathrm{SD} 3.0 \times 10^{-3}\right)$ and $5.0 \times 10^{-2}$ molecules in progressor patients $\left(\mathrm{SD} 6.5 \times 10^{-2}\right.$; $P<0.001$, Mann-Whitney rank test). The difference between the mean values obtained for the two groups of patients for multispliced transcripts ( $>30$-fold) was even greater for the mRNA of genomic length. This transcript was found in peripheral blood CD4+ cells at a frequency of $4.6 \times 10^{-3}$ molecules/ $\beta$-actin molecule in nonprogressors (SD $7.0 \times 10^{-3}$ ) and 3.76 molecules $/ \beta$-actin molecule in progressor patients (SD 4.33; $P<0.001$, Mann-Whitney rank test; $>800 \times$ difference between the mean value of the two groups). Considering that $\beta$-actin is a highly transcribed gene, these values indicate that transcription of the provirus is a highly sustained process in patients with HIV disease and that this process takes place also in peripheral blood CD4+ cells. According to this observation, when the pattern of virus transcription was correlated to the levels of viremia, a strict correlation was found between the intracellular levels of unspliced transcripts (but not of multi-
A

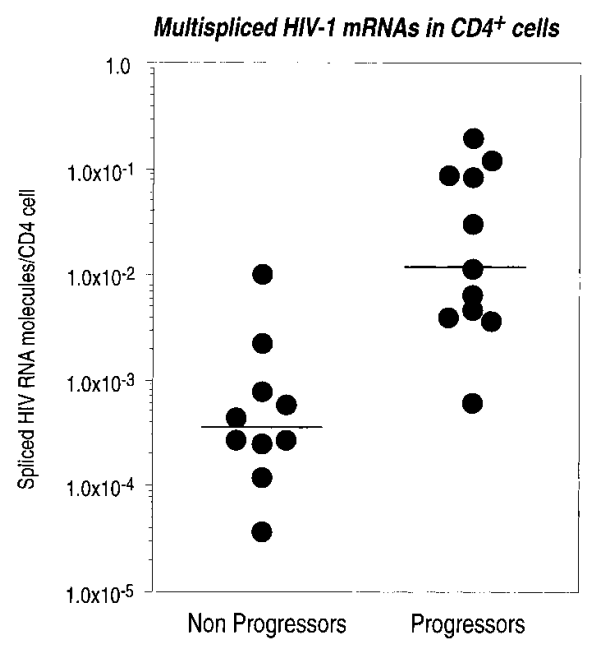

B

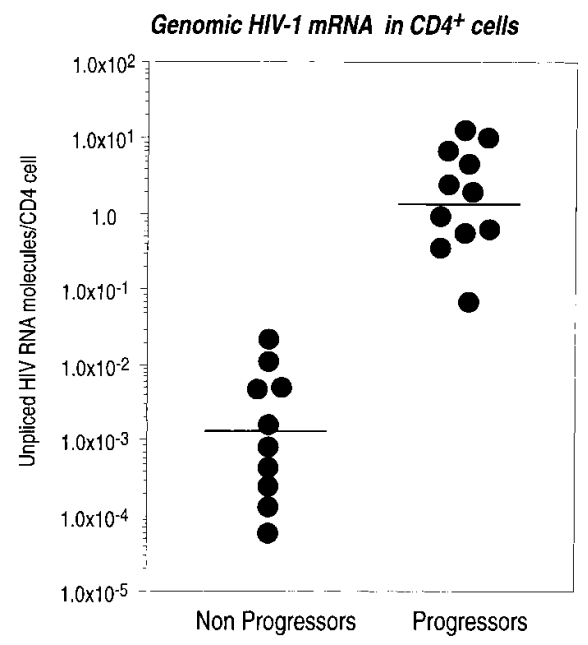

Figure 3. Expression of viral mRNAs in peripheral blood CD4+ cells. The levels of multispliced Rev mRNA $(A)$ and full length genomic RNA $(B)$ are shown for the population of nonprogressor and progressor patients. The values correspond to the number of HIV mRNA molecules of the two classes after standardization for the $\beta$-actin mRNA levels quantified in each total RNA sample and according to the percentage of CD4+ cells (see Table II). 
spliced transcripts) and the amount of virus RNA in plasma (Spearman rank correlation test, $P<0.001$ ). While a potential caveat of this observation is that unspliced mRNA levels are also contributed by binding of virions to CD4 cells, the simplest molecular explanation is that the proviral DNA in progressor patients is committed to the production of unspliced RNAs for the assembly and release of new viral particles.

Virus transcription pattern. The above reported quantitative determinations on the levels of HIV RNAs clearly indicate that a dramatic burst of viral replication exists in patients with progressive HIV infection, and that this is reflected at the cellular level by the accumulation of virus-specific mRNAs. The question arises whether this burst could be due to the increased transcriptional rate of the provirus, or if it results from the expansion of the pool of infected cells and the subsequent existence of more proviral DNA molecules, which act as templates for viral RNA transcription. To address this issue, we studied the levels of viral multispliced and unspliced mRNAs with respect to the levels of proviral DNA molecules in CD4+ cells. The results of these evaluations are presented for each transcript class in the respective rightmost columns in Table II (HIV RNA/provirus), and are graphically shown in Fig. 4 for the two groups of patients. The values are expressed as the number of spliced and unspliced HIV mRNA molecules (Fig. $4, A$ and $B$, respectively) transcribed by each molecule of proviral DNA; exact standardization of the competitive PCR quantifications was obtained by measurement of the cellular $\beta$-actin mRNA molecules in RNA samples for HIV transcripts and of cellular $\beta$-globin gene copy number in DNA samples. Therefore, these results truly depict the transcriptional activity of the provirus in peripheral blood mononuclear cells of the patients. Surprisingly, analysis of the results indicates that the transcriptional activity of the provirus was remarkably different in the two groups. The production of multispliced transcripts was increased in nonprogressor patients (mean, $2.0 \times$
$10^{-1}$ Rev mRNA molecules/HIV provirus; SD $\left.2.7 \times 10^{-1}\right)$ with respect to progressor patients (mean, $2.1 \times 10^{-2} \mathrm{Rev}$ mRNA molecules/provirus; SD $2.9 \times 10^{-1} ; P<0.05$, Mann-Whitney rank test). This $\sim 10 \times$ difference in the mean values of short RNA transcripts between the two groups was completely reversed when the genomic-length viral RNA was considered. In this case, patients with nonprogressive HIV infection had $\sim 4 \times$ less viral RNA per provirus than patients with progressive infection (nonprogressors mean value, 1.4 unspliced mRNA molecules/HIV provirus; SD 2.1; progressor mean value, 5.0 unspliced mRNA molecules/provirus; SD 6.8; $P<$ 0.05 , Mann-Whitney rank test). Accordingly, when the ratio between the two viral transcript classes was considered, patients with nonprogressive infection had a mean value of 1.45 short Rev transcripts/unspliced transcript in their peripheral blood cells (SD 3.06), while patients with progressive infection had 0.01 short transcripts per unspliced RNA (SD 0.26; $P<$ $0.01)$. These values are shown in the rightmost column of Table II and plotted in Fig. 4 C.

Altogether, these observations indicate that the pattern of HIV-1 gene expression in patients with nonprogressive infection is remarkably different from that found in patients with HIV disease. Viral RNA transcription in the former group of patients resembles the one detectable during the latent phase in chronically infected cell lines in which expression is inducible $(18,19,37)$, or during the early phases of the experimental infection of susceptible CD4+ cells $(25,26)$.

\section{Discussion}

Similar to all retroviruses, one of the major determinants of the rate of HIV replication is the regulation of provirus gene expression in infected cells, which is accomplished by a complex network of protein-DNA and protein-RNA interactions involving both cellular and viral factors and connecting the
A

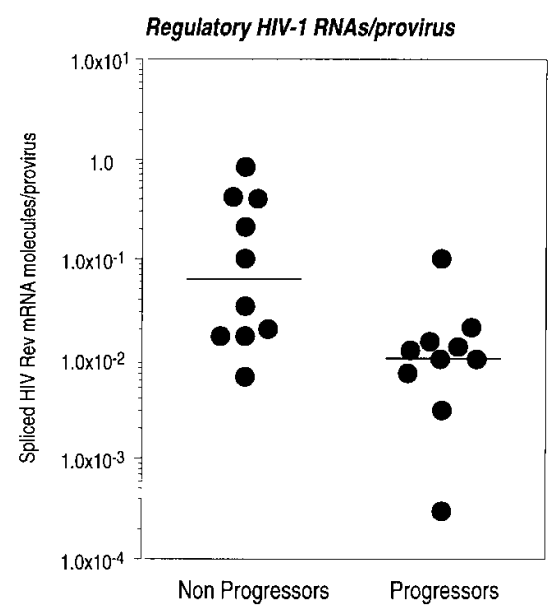

B

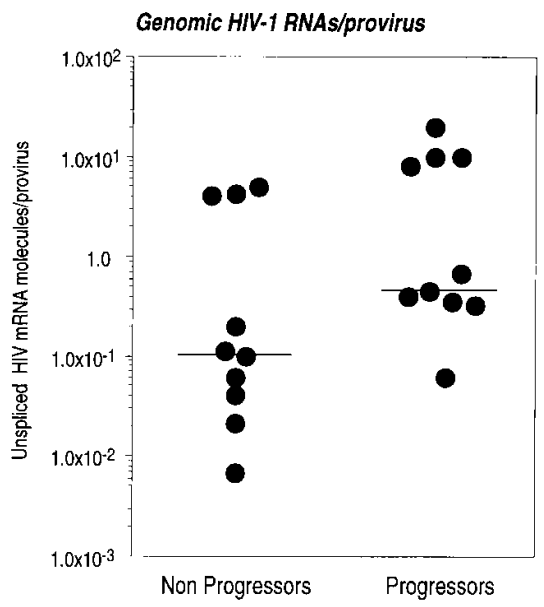

C

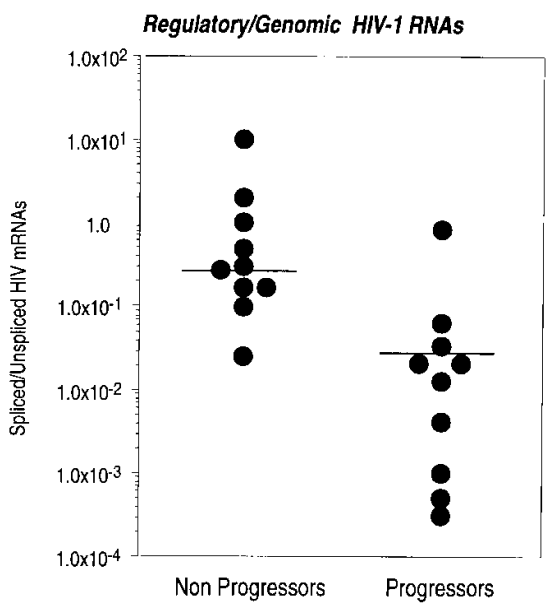

Figure 4. Pattern of provirus gene expression. $(A$ and $B)$ The graphs show the level of multispliced Rev mRNA $(A)$ and full length genomic HIV RNA $(B)$ for the two populations of patients, calculated as the number of viral RNA molecules expressed per provirus DNA copy. Provirus gene expression is prevalently engaged in the production of multispliced mRNAs in individuals nonprogressing toward HIV disease, while the opposite occurs in patients with progressive disease. $(C)$ Ratio between HIV multispliced Rev mRNA and genomic length mRNA in the two populations of patients. 
control of virus gene expression to the regulation of cellular proliferation and metabolism. These mechanisms involve the control of both provirus transcription rate, which generates a single mRNA of genomic length, and of posttranscriptional processing of this transcript. While it has been relatively easy to study the pattern of HIV gene expression in experimental systems, obtaining interesting information about the regulation of these processes, these studies in infected patients have been hampered by the difficulty of getting truly quantitative data given the relatively low levels at which HIV transcripts are found in vivo. Still, several important questions need to be answered about the natural history of infection that could take advantage of the exact understanding of the kinetics of HIV replication. These include the existence of a true latency phase at the single cell level and its relationship with the CD4+ activation state; the role of transcriptional activation of the provirus by inducible cellular factors and by extracellular Tat protein; the function of RNA processing and translational mechanism in preventing virion protein and genomic RNA production. The understanding of some of these issues can take advantage of truly quantitative competitive PCR studies on biological samples from HIV-infected individuals.

In this work, we have addressed the issue of understanding the kinetics of HIV-1 replication in the development of HIV disease by contrasting the quantification of HIV mRNAs in samples from patients with nonprogressive infection with that from patients with the same temporal history of infection but with clear progression of the disease. Several quantitative differences were found between these two groups of individuals: (a) the mean levels of viral RNA in plasma were increased more than $3,000 \times$ in progressor patients with respect to nonprogressor individuals; $(b)$ the mean levels of provirus copies in peripheral blood CD4+ cells were increased more than 400fold in progressors; $(c)$ the levels of unspliced and multispliced transcripts in progressors were more than 800 and $30 \times$, respectively, higher than those in nonprogressors; $(d)$ short, multispliced HIV transcripts produced per provirus DNA copy were $12 \times$ more abundant in peripheral blood cells of nonprogressors, while long unspliced RNAs were more than $3 \times$ as abundant in samples from progressors. These results clearly indicate not only that viral load is dramatically divergent in the two groups of patients, as suggested by previous studies (50, 51), but also that the kinetics of HIV gene expression, including the pattern of virus mRNA processing, is different.

The quantitative HIV mRNA evaluations were performed in RNA samples from peripheral blood. Interestingly, when the levels of viremia (which is expected to reflect viral load in the lymphoid system; reference 57) and the levels of peripheral blood cells harboring HIV genomes were considered for the overall sample population, a strict correlation was found between the two variables. This observation, together with the finding that active proviral DNA transcription occurs in peripheral blood CD4+ cells, suggests that these cells actively participate in the highly dynamic turnover occurring during HIV infection, and supports the notion that their analysis is appropriate to understanding the kinetics of HIV replication. Additionally, it should be also observed that in the majority of both progressors and nonprogressors, the viral RNA/DNA ratios, representing the provirus transcriptional activity, are $\leq 1$; this indicates that in several cells the provirus is in an inactive state.

The finding that the pattern of provirus transcription is re- markably different in patients not progressing toward overt disease deserves further comment. The prevalent production of regulatory transcript mRNAs, with respect to HIV genome RNA, is a hallmark of the first phases of the experimental infection, when virus production is still not detectable and there is accumulation of viral regulatory proteins (58). Additionally, this is the same pattern that can be found in chronically infected cell lines that produce undetectable amounts of virus and have been taken as a model for the study of viral latency $(17,18,37)$. Production of replicative virus in these cells lines can be obtained by cellular stimulation with various agents that trigger cellular activation and proliferation. The finding of a similar "latency" pattern in samples of nonprogressor individuals suggests that viral replication in these individuals is a highly controlled process, with respect to progressor patients showing runaway replication and subsequent production of massive amounts of viral genomes.

While the analysis of long term nonprogressor individuals in contrast with progressor patients emphasizes this different pattern of HIV gene expression, it should be considered that a pattern resembling the early phase of infection is likely to be present also in patients during the asymptomatic phase of infection, regardless whether they will become long term nonprogressors or not. Accordingly, the dysregulation of the mechanisms controlling these events is likely to occur progressively during the course of the infection, as also suggested both by longitudinal studies $(15,29)$ and by studies analyzing the factors that predict the rate of disease progression (14).

Finally, it is of great interest to understand which are the mechanisms responsible for the maintenance of the early pattern of virus gene expression in nonprogressor individuals. These mechanisms can act on the organism level, by more efficient clearance of cells engaged in virus production by cytotoxic T-lymphocytes in nonprogressors (59). Alternatively, they can act at the posttranscriptional level in each infected cell by interfering with the export of unspliced mRNA, which is required for a fully productive infection. In both cases, the definition of such mechanisms would represent a very important goal for the understanding of the molecular correlates of disease progression in HIV-1-infected individuals.

\section{Acknowledgments}

This work was supported by grants of the AIDS program of the Istituto Superiore di Sanita' (Rome, Italy) to M. Giacca and U. Tirelli. M. Comar is supported by a fellowship of the Children Hospital "Burlo Garofolo" (Trieste, Italy).

\section{References}

1. Ho, D.D., T. Moudgil, and M. Alam. 1989. Quantitation of human immunodeficiency virus type 1 in the blood of infected persons. N. Engl. J. Med. 321: 1621-1625.

2. Bagnarelli, P., S. Menzo, A. Valenza, A. Manzin, M. Giacca, F. Ancarani, G. Scalise, P.E. Varaldo, and M. Clementi. 1992. Molecular profile of human immunodeficiency virus infection in asymptomatic subjects and AIDS patients. J. Virol. 66:7328-7335.

3. Michael, N.L., M. Vahey, D.S. Burke, and R.R. Redfield. 1992. Viral DNA and mRNA expression correlate with the stage of human immunodeficiency virus (HIV) type 1 infection in humans: evidence for viral replication in all stages of HIV disease. J. Virol. 66:310-316.

4. Connor, R.I., H. Mohri, Y. Cao, and D.D. Ho. 1993. Increased viral burden and cytopathicity correlate temporally with CD4+ T-lymphocyte decline and clinical progression in human immunodeficiency virus type 1-infected individuals. J. Virol. 67:1772-1777.

5. Schnittman, S.M., J.J. Greenhouse, M.C. Psallidopoulos, M. Baseler, N.P. 
Salzman, A.S. Fauci, and H.C. Lane. 1990. Increasing viral burden in CD4+ T cells from patients with human immunodeficiency virus (HIV) infection reflects rapidly progressive immunosuppression and clinical disease. Ann. Intern. Med. 113:438-443.

6. Schnittman, S.M., J.J. Greenhouse, H.C. Lane, P.F. Pierce, and A.S. Fauci. 1991. Frequent detection of HIV-1-specific mRNAs in infected individuals suggests ongoing active viral expression in all stages of disease. AIDS Res. Hum. Retroviruses. 7:361-367.

7. Jurriaans, S., J.T. Dekker, and A. de Ronde. 1992. HIV-1 viral DNA load in peripheral blood mononuclear cells from seroconverters and long-term infected individuals. AIDS (Lond.). 6:635-641.

8. Simmonds, P., P. Balfe, J.F. Peutherer, C.A. Ludlam, J.O. Bishop, and A.J. Brown. 1990. Human immunodeficiency virus-infected individuals contain provirus in small numbers of peripheral mononuclear cells and at low copy numbers. J. Virol. 64:864-872.

9. Gupta, P., L. Kingsley, J. Armstrong, M. Ding, M. Cottrill, and C. Rinaldo. 1993. Enhanced expression of human immunodeficiency virus type 1 correlates with development of AIDS. Virology. 196:586-595.

10. Piatak, M., Jr., M.S. Saag, L.C. Yang, S.J. Clark, J.C. Kappes, K.-C. Luk, B.H. Hahn, G.M. Shaw, and J.D. Lifson. 1993. High levels of HIV-1 in plasma during all stages of infection determined by competitive PCR. Science (Wash. DC). 259:1749-1754

11. Bagasra, O., S.P. Hauptman, H.W. Lischner, M. Sachs, and R.J. Pomerantz. 1992. Detection of human immunodeficiency virus type 1 provirus in mononuclear cells by in situ polymerase chain reaction. N. Engl. J. Med. 326: 1385-1391.

12. Patterson, B.K., M. Till, P. Otto, C. Goolsby, M.R. Furtado, L.J. McBride, and S.M. Wolinsky. 1993. Detection of HIV-1 DNA and messenger RNA in individual cells by PCR-driven in situ hybridization and flow cytometry. Science (Wash. DC). 260:976-979.

13. Saksela, K., C. Stevens, P. Rubinstein, and D. Baltimore. 1994. Human immunodeficiency virus type $1 \mathrm{mRNA}$ expression in peripheral blood cells predicts disease progression independently of the numbers of CD4+ lymphocytes. Proc. Natl. Acad. Sci. USA. 91:1104-1108.

14. Wong, M.T., M.J. Dolan, R.D. Kozlow, G.P. Melcher, D.S. Burke, R. Neal Boswell, and M. Vahey. 1996. Patterns of virus burden and T-cell phenotype are established early and are correlated with the rate of disease progression in human immunodeficiency virus type 1 -infected persons. J. Infect. Dis. 173:877-887.

15. Michael, N.L., T. Mo, A. Merzouki, M. O'Shaughnessy, C. Oster, D.S. Burke, R.R. Redfield, D.L. Birx, and S.A. Cassol. 1995. Human immunodeficiency virus type 1 cellular RNA load and splicing patterns predict disease progression in a longitudinally studied cohort. J. Virol. 69:1868-1877.

16. Saksela, K., C.E. Stevens, P. Rubinstein, P.E. Taylor, and D. Baltimore. 1995. HIV-1 messenger RNA in peripheral blood mononuclear cells as an early marker of risk for progression to AIDS. Ann. Intern. Med. 123:641-648.

17. Pomerantz, R.J., D. Trono, M.B. Feinberg, and D. Baltimore. 1990. Cells nonproductively infected with HIV-1 exhibit an aberrant pattern of viral RNA expression: a molecular model for latency. Cell. 61:1271-1276.

18. Michael, N.L., P. Morrow, J. Mosca, M. Vahey, D.S. Burke, and R.R. Redfield. 1991. Induction of human immunodeficiency virus type 1 expression in chronically infected cells is associated primarily with a shift in RNA splicing patterns. J. Virol. 65:1291-1303.

19. Demarchi, F., P. D'Agaro, A. Falaschi, and M. Giacca. 1993. In vivo footprinting analysis of constitutive and inducible protein-DNA interactions at the long terminal repeat of human immunodeficiency virus type 1. J. Virol. 67: $7450-7460$.

20. Embretson, J., M. Zupancic, J.L. Ribas, A. Burke, P. Racz, K. TennerRacz, and A.T. Haase. 1993. Massive covert infection of helper T lymphocytes and macrophages by HIV during the incubation period of AIDS. Nature (Lond.). 362:359-362.

21. Pantaleo, G., C. Graziosi, J.F. Demarest, L. Butini, M. Montroni, C.H. Fox, J.M. Orenstein, D.P. Kotler, and A.S. Fauci. 1993. HIV infection is active and progressive in lymphoid tissue during the clinically latent stage of disease. Nature (Lond.). 362:355-358.

22. Chun, T.W., D. Finzi, J. Margolick, K. Chadwick, D. Schwartz, and R.F. Siliciano. 1995. In vivo fate of HIV-1-infected T cells: quantitative analysis of the transition to stable latency. Nat. Med. 1:1284-1290.

23. Schwartz, S., B.K. Felber, D.M. Benko, E.M. Fenyo, and G.N. Pavlakis. 1990. Cloning and functional analysis of multiply spliced mRNA species of human immunodeficiency virus type 1. J. Virol. 64:2519-2529.

24. Schwartz, S., B.K. Felber, E.M. Fenyo, and G.N. Pavlakis. 1990. Env and $\mathrm{Vpu}$ proteins of human immunodeficiency virus type 1 are produced from multiple bicistronic mRNAs. J. Virol. 64:5448-5456.

25. Kim, S., R. Byrn, J. Groopman, and D. Baltimore. 1989. Temporal aspects of DNA and RNA synthesis during human immunodeficiency virus infection: evidence for differential gene expression. J. Virol. 63:3708-3713.

26. Klotman, M.E., S. Kim, A. Buchbinder, A. DeRossi, D. Baltimore, and F. Wong-Staal. 1991. Kinetics of expression of multiply spliced RNA in early human immunodeficiency virus type 1 infection of lymphocytes and monocytes. Proc. Natl. Acad. Sci. USA. 88:5011-5015.

27. Pomerantz, R.J., T. Seshamma, and D. Trono. 1992. Efficient replica- tion of human immunodeficiency virus type 1 requires a threshold level of Rev: potential implications for latency. J. Virol. 66:1809-1813.

28. Seshamma, T., O. Bagasra, T. Trono, D. Baltimore, and R.J. Pomerantz. 1992. Blocked early-stage latency in the peripheral blood cells of certain individuals infected with human immunodeficiency virus type 1. Proc. Natl. Acad. Sci. USA. 89:10663-10667.

29. Furtado, M.R., L.A. Kingsley, and S.M. Wolinsky. 1995. Changes in the viral mRNA expression pattern correlate with a rapid rate of $\mathrm{CD} 4+\mathrm{T}$-cell number decline in human immunodeficiency virus type 1 -infected individuals. J. Virol. 69:2092-2100.

30. Diviacco, S., P. Norio, L. Zentilin, S. Menzo, M. Clementi, G. Biamonti, S. Riva, A. Falaschi, and M. Giacca. 1992. A novel procedure for quantitative polymerase chain reaction by coamplification of competitive templates. Gene (Amst.). 122:313-320.

31. Giacca, M., L. Zentilin, P. Norio, S. Diviacco, D. Dimitrova, G. Contreas, G. Biamonti, G. Perini, F. Weighardt, S. Riva, and A. Falaschi. 1994. Fine mapping of a replication origin of human DNA. Proc. Natl. Acad. Sci. USA. 91: $7119-7123$.

32. Grassi, G., L. Zentilin, S. Tafuro, S. Diviacco, A. Ventura, and M. Giacca. 1994. A rapid procedure for the quantitation of low abundance mRNAs by competitive RT-PCR. Nucleic Acids Res. 22:4547-4549.

33. Grassi, G., G. Pozzato, M. Moretti, and M. Giacca. 1995. Quantitative analysis of hepatitis $\mathrm{C}$ virus RNA in liver biopsies by competitive reverse transcription and polymerase chain reaction. J. Hepatol. 23:403-411.

34. Pelizon, C., S. Diviacco, A. Falaschi, and M. Giacca. 1996. High resolution mapping of the origin of DNA replication in the hamster dihydrofolate reductase gene domain by competitive polymerase chain reaction. Mol. Cell. Biol. 16:5358-5364.

35. Tafuro, S., L. Zentilin, A. Falaschi, and M. Giacca. 1996. Rapid retrovirus titration using competitive polymerase chain reaction. Gene Ther. 3:679684

36. Bagnarelli, P., A. Valenza, S. Menzo, A. Manzin, G. Salise, P.E. Varaldo, and M. Clementi. 1994. Dynamics of molecular parameters of human immunodeficiency virus type 1 activity in vivo. J. Virol. 68:2495-2502.

37. Comar, M., G. Marzio, P. D'Agaro, and M. Giacca. 1996. Quantitative dynamics of HIV-1 expression. AIDS Res. Hum. Retroviruses. 12:117-126.

38. Giacca, M., S. Zanussi, M. Comar, C. Simonelli, E. Vaccher, P. de Paoli, and U. Tirelli. 1996. Treatment of HIV infection with hydroxyurea: virological and clinical evaluation. J. Infect. Dis. 174:204-209.

39. Menzo, S., P. Bagnarelli, M. Giacca, A. Manzin, P.E. Varaldo, and M. Clementi. 1992. Absolute quantitation of viremia in HIV-infected asymptomatic subjects by competitive reverse-transcription and polymerase chain reaction. J. Clin. Microbiol. 30:1752-1757.

40. De Rossi, A., S. Masiero, C. Giaquinto, E. Ruga, M. Comar, M. Giacca, and L. Chieco-Bianchi. 1996. Dynamics of viral replication in infants with vertically acquired human immunodeficiency virus type 1 . J. Clin. Invest. 97:323330 .

41. Zanussi, S., C. Simonelli, M. D’Andrea, M. Comar, E. Bidoli, M. Giacca, U. Tirelli, E. Vaccher, and P. De Paoli. 1996. The effects of antineoplastic chemotherapy on HIV disease. AIDS Res. Hum. Retroviruses. 12:1703-1707.

42. Sheppard, H.W., W. Lang, M.S. Asher, E. Vittinghoff, and W. Wilkelstein. 1993. The characterization of non-progressors: long-term HIV-1 infection with stable CD4+ T-cell levels. AIDS (Lond.). 7:1159-1166.

43. Buchbinder, S.P., M.H. Katz, N.A. Hessol, P.M. O'Malley, and S.D. Holmberg. 1994. Long-term HIV-1 infection without immunologic progression. AIDS (Lond.). 8:1123-1128.

44. Greenough, T.C., M. Somasundaran, D.B. Brettler, R.M. Hesselton, A Alimenti, F. Kirchhoff, D. Panicali, and J.L. Sullivan. 1994. Normal immune function and inability to isolate virus in culture in an individual with long-term human immunodeficiency virus type 1 infection. AIDS Res. Hum. Retroviruses. 10:395-403.

45. Easterbrook, P.J. 1994. Non-progression in HIV infection. AIDS (Lond.). 8:1179-1182.

46. Keet, I.P., A. Krol, M.R. Klein, P. Veugelers, J. de Wit, M. Roos, M Koot, J. Goudsmit, F. Miedema, and R.A. Coutinho. 1994. Characteristics of long-term asymptomatic infection with human immunodeficiency virus type 1 in men with normal and low CD4+ cell counts. J. Infect. Dis. 169:1236-1243.

47. Learmont, J., B. Tindall, L. Evans, A. Cunningham, P. Cunningham, J. Wells, R. Penny, J.K. Aldor, and D.A. Cooper. 1992. Long-term symptomless HIV-1 infection in recipients of blood products from a single donor. Lancet. 340:863-867.

48. Michael, N.L., G. Chang, L.A. d'Arcy, P.K. Ehrenberg, R. Mariani, M.P. Busch, D.L. Birx, and D.H. Schwartz. 1995. Defective accessory genes in a human immunodeficiency virus type 1-infected long-term survivor lacking recoverable virus. J. Virol. 69:4228-4236.

49. Kirchhoff, F., T.C. Greenough, D.B. Brettler, J.L. Sullivan, and R.C Desrosier. 1995. Absence of intact nef sequences in long-term survivor with nonprogressive HIV-1 infection. N. Engl. J. Med. 332:228-232.

50. Cao, Y., L. Qin, L. Zhang, J. Safrit, and D.D. Ho. 1995. Virologic and immunologic characterization of long-term survivors of human immunodeficiency virus type 1 infection. N. Engl. J. Med. 332:201-208.

51. Pantaleo, G., S. Menzo, M. Vaccarezza, C. Graziosi, O.J. Cohen, J.F. 
Demarest, D. Montefiori, J.M. Orenstein, C. Fox, L.K. Schrager, et al. 1995. Studies in subjects with long-term nonprogressive human immunodeficiency virus infection. N. Engl. J. Med. 332:209-216.

52. Schwartz, D., U. Sharma, M. Busch, K. Weinhold, T. Matthews, J. Lieberman, D. Birx, H. Farzedagen, J. Margolick, and T. Quinn. 1994. Absence of recoverable infectious virus and unique immune responses in an asymptomatic HIV+ long-term survivor. AIDS Res. Hum. Retroviruses. 10:1703-1711.

53. Montefiori, D.C., G. Pantaleo, L.M. Fink, J.T. Zhou, J.Y. Zhou, M. Bilska, G.D. Miralles, and A.S. Fauci. 1996. Neutralizing and infection-enhancing antibody responses to human immunodeficiency virus type 1 in long-term nonprogressors. J. Infect. Dis. 173:60-67.

54. Sambrook, J., E.F. Fritsch, and T. Maniatis. 1989. Molecular Cloning. A Laboratory Manual. 2nd ed. Cold Spring Harbor Laboratory, Cold Spring Harbor, NY. pp. 9.16-9.19.

55. Chomczynski, P., and N. Sacchi. 1987. Single-step method of RNA isolation by acid guanidium thiocyanate-phenol-chloroform extraction. Anal. Bio- chem. 162:156-159.

56. Zanussi, S., C. Simonelli, M. D'Andrea, C. Caffau, M. Clerici, U. Tirelli, and P. DePaoli. 1996. CD8+ lymphocyte phenotype and cytokine production in long-term non-progressor and in progressor patients with HIV-1 infection. Clin. Exp. Immunol. 105:220-224.

57. Dianzani, F., G. Antonelli, E. Riva, S. Uccini, and G. Visco. 1996 Plasma HIV viremia and viral load in lymph nodes - letter. Nat. Med. 2:832-833.

58. Cullen, B.R., and W.C. Greene. 1989. Regulatory pathways governing HIV-1 replication. Cell. 58:423-426.

59. Huynen, M.A., and A.U. Neumann. 1996. Rate of killing of HIV-infected T cells and disease progression. Science (Wash. DC). 272:1962.

60. Myers, G., S. Wain-Hobson, B. Korber, R.F. Smith, and G.N. Pavlakis 1993. Human retroviruses and AIDS 1993 I-II: a compilation and analysis of nucleic acid and amino acid sequences. Los Alamos National Laboratory, Los Alamos, NM. 